\title{
Water Inrush Risk Assessment under Fuzzy Analytic Hierarchy Process in Guizhou Province
}

\author{
Yongyan Yu \\ Research Institute of Highway Ministry of Transport, Beijing 100088, China \\ 535165839@qq.com
}

Keywords: Highway tunnel; Fuzzy analytic hierarchy process; Risk assessment; water inrush

\begin{abstract}
Fuzzy analytic hierarchy process is used to establish risk evaluation model on water inrush based on the characters of highway tunnel in Guizhou province. In the process of mode, risk factors are evaluated, based on statistical analysis on water inrush in china, and on the characters of tunnel in Guizhou province. Considered similar projects and survey from experts, relative scale methodology is used to obtain weight value on risk factors. The mode is used in tunnel in Guizhou province to obtain the possibility of water inrush. Model calculation results are in conformity with engineering evaluation. Consequently, the mode is reasonable, which could be used in evaluate water inrush in Guizhou tunnel.
\end{abstract}

\section{Introduction}

The western of China is widely distributed with karst. It is inevitable to meet water inrush in construction $^{[1-2]}$, When tunnel located in strong Karst area. So risk assessment on water inrush in tunnels in those areas is very important.

Large amount of risk assessments accords to "Road Tunnel and Bridge Construction Risk Assessment Guide". Assessments based on the Guidelines are scored on impact factors. However, when some factors do not exist, the total score will be reduced and accuracy affected. When using the analytic hierarchy process (AHP), the matrix is used to calculate the weight, and when one of the influencing factors does not exist, the weight can be automatically adjusted; So AHP could reduce the influence of the lack of some factors on evaluation

Based on the fuzzy analytic hierarchy process and the characteristics of the tunnel in Guizhou province, this study establishes water inrush risk assessment model, to make up the reduced accuracy because of lack of factors. By analyzing the tunnel constructions in China, the factors that have great influence on the inrush are selected. And hierarchical model is established based on the correlation of the factors. According to the characteristics of the geological conditions in Guizhou province, the relative weight of the influencing factors is obtained by considering the statistical results and the expert survey results, and the appropriate membership function is selected. By applying the model to the Chong-an River tunnel in Guizhou Province, the results are consistent with the engineering evaluation.

\section{Evaluation Analysis Model}

\subsection{Evaluation factors}

The relevant research results of inrush indicate that the main factors can be summarized as: Karst degree, rock slope, rock thickness, and rock combination, fault properties, joint fracture, Karst hydrodynamic zone, groundwater level, surface Karst, catchments area. Based on collection and collation of data over 100 cases of Karst water inrush in China, the typical influencing factors for water inrush are: Formation lithology, geological formation, groundwater level, geomorphology, rock formation, soluble rock and non-soluble rock contact zone, layers and interlayer fractures. ${ }^{[3]}$ 


\subsection{Establishment of hierarchy model}

It can be concluded that the main risk factors of water inrush are formation lithology, geological formations, impact of water and topographical. Table 1 shows indicator system for risk assessment of water inrush.

Table1 Indicator System for Risk Assessment of Tunnel Water Inrush

\begin{tabular}{|c|c|c|}
\hline Target layerA & Guidelines layer B & Indicator layer $\mathrm{C}$ \\
\hline \multirow{11}{*}{$\begin{array}{lr}\text { Inrush risk } \\
\text { indicators (A) }\end{array}$} & \multirow[t]{3}{*}{ Formation lithology $B_{1}$} & Karst degree $\mathrm{C}_{11}$ \\
\hline & & Rock thickness $\mathrm{C}_{12}$ \\
\hline & & Rock formations $C_{13}$ \\
\hline & \multirow[t]{3}{*}{ Geological formations $\mathrm{B}_{2}$} & Fault $\mathrm{C}_{21}$ \\
\hline & & Wrinkle $\mathrm{C}_{22}$ \\
\hline & & Channels and fissures $\mathrm{C}_{23}$ \\
\hline & \multirow[t]{3}{*}{ Impact of water $B_{3}$} & Groundwater development $\mathrm{C}_{31}$ \\
\hline & & Effects of precipitation $\mathrm{C}_{32}$ \\
\hline & & Groundwater level difference $\mathrm{C}_{33}$ \\
\hline & \multirow[t]{2}{*}{ Topographical features $\mathrm{B}_{4}$} & Surface KarstC 41 \\
\hline & & Water-absorbing area $\mathrm{C}_{42}$ \\
\hline
\end{tabular}

\subsection{Determination of relative weight}

In the calculation, Saulty $1 \sim 9$ matrix scale method is used to compare the importance of various factors. The relative weight of quantization is described by $a_{i j}$, with n elements participating in each matrix. The result should be tested consistently to ensure the correctness of the selection.

Table 2 Salty relative scale method ${ }^{[3]}$

\begin{tabular}{|l|l|l|l|l|l|l|l|}
\hline \multicolumn{1}{|c|}{ Scale } & 1 & \multicolumn{1}{c|}{3} & 5 & 7 & 9 & $2,4,6,8$ & $a_{j i}$ \\
\hline $\begin{array}{l}\text { Importance of } \\
\text { factor } \begin{array}{l}\text { Equal } \\
\text { compared with } \\
\text { factor } j\end{array}\end{array}$ & $\begin{array}{l}\text { A little } \\
\text { important. }\end{array}$ & Obviously & Strong & extremely & $\begin{array}{l}\text { Interpolation } \\
\text { between } \\
\text { odd scales of } \\
\text { importance }\end{array}$ & $a_{j i}=1 / a_{i j}$ \\
\hline
\end{tabular}

The accuracy of relative weights is crucial on the risk assessment. In order to ensure the property of value, the engineering analogy and the expert investigation has been considered. According to survey of experts, the relative scale value is obtained. The experts selected come from scientific Institutes, Universities, design units, and construction units. Most of experts have associate professor or above professional title. They have worked in tunnel construction fields for many years, and familiar with engineering risk assessment theory and methods. A total of 22 persons participated in the expert survey. 3 of them from construction units, 6 of them from design units, 5 of them from universities, and 8 of them from scientific institutes. Of the 22 persons, 7 are professors and professors, 9 are associate professors or senior teachers, 4 are intermediate titles, and 2 are junior titles. Two persons have worked in tunnel fields for 5-10 years, five in 10-15 years, eight in 15-20 years, and seven in 20-plus years.

Table3 Classification and weight selection of experts

\begin{tabular}{|l|l|l|l|l|}
\hline Level & A & B & C & D \\
\hline technical title & $\begin{array}{l}\text { professor } \\
\text { Senior } \\
\text { Professors }\end{array}$ & $\begin{array}{l}\text { associate } \\
\text { professor } \\
\text { Senior Engineer }\end{array}$ & $\begin{array}{l}\text { Intermediate } \\
\text { title }\end{array}$ & Junior titles \\
\hline working years in tunnels field & $>20$ years & $15-20$ years & 10 -15 years & $5-10$ years \\
\hline $\begin{array}{l}\text { Level of familiarity with risk assessment } \\
\text { theory and methodology }\end{array}$ & Professional & $\begin{array}{l}\text { Extremely } \\
\text { understanding }\end{array}$ & understanding & $\begin{array}{l}\text { Partial } \\
\text { understanding }\end{array}$ \\
\hline Expert weight & 1.0 & 0.9 & 0.8 & 0.7 \\
\hline
\end{tabular}

Based on the results of engineering analogy and the expert survey, the value of the Saulty is shown in Table 4 and Table 5. 
Table 4 Criteria Layer B Judgment Matrix for Target Layer A

\begin{tabular}{|l|l|l|l|l|}
\hline & $\mathrm{B}_{1}$ & $\mathrm{~B}_{2}$ & $\mathrm{~B}_{3}$ & $\mathrm{~B}_{4}$ \\
\hline $\mathrm{B}_{1}$ & 1 & $1 / 3$ & $1 / 2$ & $1 / 3$ \\
\hline $\mathrm{B}_{2}$ & 3 & 1 & 2 & 1 \\
\hline $\mathrm{B}_{3}$ & 2 & 1 & 1 & $1 / 2$ \\
\hline $\mathrm{B}_{4}$ & 3 & $1 / 2$ & 2 & 1 \\
\hline
\end{tabular}

Eigenvector $W=\{0.111,0.358,0.229,0.301\}^{T}, \lambda_{\max }=4.12, C I=0.04, C R=0.04<0.1$, satisfied with consistency check。

Table 5 the judgment matrix of indicator layer $\mathrm{C}$ aligned with criterion layer $\mathrm{B}$ judgment matrix to $B_{1} \quad$ judgment matrix to $B_{2} \quad$ judgment matrix to $B_{3} \quad$ judgment matrix to $B_{4}$

\begin{tabular}{|l|l|l|l|}
\hline & $\mathrm{C}_{11}$ & $\mathrm{C}_{12}$ & $\mathrm{C}_{13}$ \\
\hline $\mathrm{C}_{11}$ & 1 & 3 & 3 \\
\hline $\mathrm{C}_{12}$ & $1 / 3$ & 1 & 1 \\
\hline $\mathrm{C}_{13}$ & $1 / 3$ & 1 & 1 \\
\hline $\mathrm{C}_{21}$ & 1 & $1 / 2$ & 3 \\
\hline $\mathrm{C}_{22}$ & 2 & 1 & 6 \\
\hline $\mathrm{C}_{23}$ & $1 / 3$ & $1 / 6$ & 1 \\
\hline
\end{tabular} \begin{tabular}{|l|l|l|l|l|l|l|l|}
\hline & $\mathrm{C}_{21}$ & $\mathrm{C}_{22}$ & $\mathrm{C}_{23}$ \\
\hline $\mathrm{C}_{31}$ & 1 & $\mathrm{C}_{31}$ & $\mathrm{C}_{32}$ & $\mathrm{C}_{33}$ \\
\hline $\mathrm{C}_{32}$ & 2 & $1 / 2$ & 1 \\
\hline $\mathrm{C}_{33}$ & $1 / 3$ & $1 / 3$ & 3 \\
\hline
\end{tabular}

\begin{tabular}{|l|l|l|}
\hline & $\mathrm{C}_{41}$ & $\mathrm{C}_{42}$ \\
\hline $\mathrm{C}_{41}$ & 1 & 2 \\
\hline $\mathrm{C}_{42}$ & $1 / 2$ & 1 \\
\hline
\end{tabular}

Eigenvector from indicator layer $C$ to Guidelines layer $\mathrm{B}_{1} \mathrm{~W}=\{0.6,0.2,0.2\}^{T}, \lambda_{\text {max }}=3.0, \quad C I=0$, $C R=0<0.1$, satisfied with consistency check. Eigenvector from indicator layer $C$ to Guidelines layer $\mathrm{B}_{2} W=\{0.3,0.6,0.1\}^{T}, \lambda_{\max }=3, C I=0, C R=0<0.1$, satisfied with consistency check. Eigenvector from indicator layer $C$ to Guidelines layer $B_{3} W=\{0.24,0.55,0.21\}^{T}, \lambda_{\text {max }}=3.02, C I=0.009$, $C R=0.018<0.1$, satisfied with consistency check. Eigenvector from indicator layer $\mathrm{C}$ to Guidelines layer $\mathrm{B}_{4} W=\{0.333,0.667\}^{T}$ 。 2 order matrix is always fully consistent, so no random consistency ratio is required.

\subsection{Determination of membership function}

Common membership function forms include triangle, trapezoid, normal distribution, type I, etc. Type I functions are mainly used in language descriptions. Triangle membership function and trapezoidal membership function are sufficient to represent other types of membership function. Considering simplicity of model, the triangle membership function is preferred. In this study, the risk factors of atmospheric precipitation and groundwater level difference can be described numerically, and the membership function can be selected by using triangular membership function. Three parameters ( $\mathrm{a}, \mathrm{b}, \mathrm{c}$ ) are commonly used to represent the membership function of a triangle. The three parameters represent the three coordinate points of the triangle, as shown in formula 1. Table 6 shows classification of factors in language descriptions.

$$
\mu_{A(x)}= \begin{cases}0 & x<a \\ (x-a) /(b-a) & a \leq x<b \\ (c-x) /(c-b) & b \leq x<c \\ 0 & c \leq x\end{cases}
$$


Table 6 Classification of factors

\begin{tabular}{|c|c|c|c|c|}
\hline Classification & $\mathrm{I}$ & II & III & IV \\
\hline Karst degree & tiny & Weak & meidum & Strong \\
\hline Rock thickness & broken & Thin & Medium thick & Thick \\
\hline Rock formations & $\begin{array}{l}\text { Horizontal overlying } \\
\text { water-resisting-layer }\end{array}$ & $\begin{array}{l}\text { Horizontal } \\
\text { underlying } \\
\text { water-resisting-layer }\end{array}$ & $\begin{array}{l}\text { Soluble and } \\
\text { insoluble contract in } \\
\text { vertical }\end{array}$ & $\begin{array}{lr}\text { Soluble } & \text { and } \\
\text { insoluble } & \text { contract } \\
\text { inclined } & \end{array}$ \\
\hline Fault & compressive fault & shear fault & $\begin{array}{l}\text { Extensional-shear } \\
\text { fault }\end{array}$ & extensional fault \\
\hline Wrinkle & $\begin{array}{l}\text { Anticline axis, water } \\
\text { catchment's } \\
\text { conditions poor }\end{array}$ & $\begin{array}{l}\text { Anticline axis, water } \\
\text { catchment's } \\
\text { conditions well }\end{array}$ & Wings of wrinkle & $\begin{array}{l}\text { Synclinal shaft, fold } \\
\text { transition }\end{array}$ \\
\hline Channels and fissures & tiny & medium & Large fissure & huge fissure \\
\hline $\begin{array}{l}\text { Groundwater } \\
\text { development }\end{array}$ & Undeveloped & develop & Rich; small inrush & $\begin{array}{l}\text { Abundant, heavy } \\
\text { inrush }\end{array}$ \\
\hline $\begin{array}{l}\text { Atmospheric } \\
\text { precipitation(mean } \\
\text { annual precipitation) }\end{array}$ & $<300$ & $300 \sim 650$ & $650 \sim 1000$ & $>1000$ \\
\hline $\begin{array}{ll}\text { groundwater } & \text { level } \\
\text { difference } / \mathrm{m} & \\
\end{array}$ & $<10$ & $10 \sim 30$ & $30 \sim 60$ & $>60$ \\
\hline $\begin{array}{ll}\text { surface } & \text { Karst } \\
\text { morphology } & \end{array}$ & $\begin{array}{l}\text { Karst shaft and karst } \\
\text { depression } \\
\text { undeveloped }\end{array}$ & $\begin{array}{l}\text { Karst shaft and karst } \\
\text { depression } \\
\text { developed medium }\end{array}$ & $\begin{array}{l}\text { Karst shaft and karst } \\
\text { depression } \\
\text { developed }\end{array}$ & $\begin{array}{l}\text { Entrance of } \\
\text { underground river } \\
\text { and karst shaft are } \\
\text { developed strongly. }\end{array}$ \\
\hline
\end{tabular}

\subsection{Fuzzy estimation of risk probability}

The probability of risk occurrence is calculated according to matrix which takes into account the factors, relative weight of factors and membership. The main method of fuzzy estimation is to multiply the eigenvector of index weight with the membership function, as shown in formula 2.

$$
B=W_{i} \cdot R_{i}=\left\{W_{1}, W_{2}, \ldots, W_{n}\right\} \cdot\left\{\begin{array}{ccc}
R_{11}, & R_{12}, \ldots, & R_{1 n} \\
R_{21}, & R_{21}, \ldots, & R_{2 n} \\
& \ldots & \\
R_{n 1}, & R_{n 2}, \ldots, & R_{n n}
\end{array}\right\}
$$

\subsection{Treatment of evaluation results}

Results treatment methods can be divided into maximum value method and the mean method. According to the maximum and mean of the membership, the evaluation index is described. This study uses the maximum value method to deal with the results. The risk of water inrush in Karst tunnel construction period is classified into four grades: low, medium, high and risky. Level I means low risk, and level IV means risky. Risk classification for water inrush is shown in table 7.

Table 7 Water inrush risk classification

\begin{tabular}{|l|l|}
\hline Risk level & division bases \\
\hline I & Risk low, water inrush less than $100 \mathrm{~m}^{3} / \mathrm{h}$ 。 \\
\hline II & $\begin{array}{l}\text { Risk medium, water inrush between } 100 \mathrm{~m}^{3} / \mathrm{h} \sim 1000 \mathrm{~m}^{3} / \mathrm{h} \text {. water bursting hazard } \\
\text { small-medium }\end{array}$ \\
\hline III & Risk high, water inrush between $1000 \mathrm{~m}^{3} / \mathrm{h} \sim 10000 \mathrm{~m}^{3} / \mathrm{h}$. water bursting hazard large \\
\hline IV & Risky, water inrush $>10000 \mathrm{~m}^{3} / \mathrm{h}$. oversize type water bursting \\
\hline
\end{tabular}

\section{Engineering Applications}

\subsection{Engineering situation}

The surface of the tunnel is strongly affected by dissolution and erosion. The altitude of the tunnel is 585.1 1068.9m. The surface bedrock is exposed as a Karst, erosion and denudation type of middle and low mountain valley landform. 
Tunnel imports above flood level $90.468 \mathrm{~m}$; the first 50m of the tunnel exit is at the junction of two mountain trenches, where annual runoff occurs. During the survey period(2013-6-1), the water flow of the track $\mathrm{Q}=3 \sim 5 \mathrm{l} / \mathrm{s}$, the water flow of the track in flood period $\mathrm{Q}=10 \sim 15 \mathrm{l} / \mathrm{s}$. Average annual precipitation in field area was $1243 \mathrm{~mm}$. $83 \%$ rainfall is concentrated from April to October. Daily maximum rainfall is $189.9 \mathrm{~mm}$.

Groundwater mainly depends on meteoric water. A small part of the rainfall is permeated at the substratum and at the joint. Joint of limestone and dolomite developed in tunnel area. Locally, there are dissolution fissures, cave distribution, water permeability. They provide good space for groundwater storage and movement. It is the main water-bearing strata in the tunnel area. The permeability of mudstone is weak, and it is the formation of water isolation.

\subsection{Water inrush Risk Assessment}

The factors would affect on water inrush are shown in Table8. And every factor in each mileage segment is analyzed. According to classification of factors in Table6, risk assessment in each factor in mileage segment is shown in table below.

Table 8 water inrush risk assessment based on each factor in mileage segments

\begin{tabular}{|c|c|c|c|c|c|}
\hline & $\begin{array}{l}\text { Left tunnel } \\
\text { ZK66+020-ZK66 } \\
+607 \\
\text { Right tunnel } \\
\text { YK65+970-YK66 } \\
+600\end{array}$ & $\begin{array}{l}\text { Left tunnel } \\
\text { ZK66+607-ZK66 } \\
+707 \\
\text { Right tunnel } \\
\text { YK66+600-YK66 } \\
+700\end{array}$ & $\begin{array}{l}\text { Left tunnel } \\
\text { ZK66+707-ZK67 } \\
+775 \\
\text { Right tunnel } \\
\text { YK66+700-YK67 } \\
+766 \\
\end{array}$ & $\begin{array}{l}\text { Left tunnel } \\
\text { ZK66+775-ZK66 } \\
+890 \\
\text { Right tunnel } \\
\text { YK66+766-YK66 } \\
+900\end{array}$ & $\begin{array}{l}\text { Left tunnel } \\
\text { ZK66+890-ZK67 } \\
+028 \\
\text { Right tunnel } \\
\text { YK66+900-ZK66 } \\
+990\end{array}$ \\
\hline Karst degree & $\begin{array}{l}\text { Medium; } \\
\text { level III }\end{array}$ & $\begin{array}{l}\text { Medium; } \\
\text { level III }\end{array}$ & $\begin{array}{l}\text { Medium; } \\
\text { level III }\end{array}$ & $\begin{array}{l}\text { Medium; } \\
\text { level III }\end{array}$ & $\begin{array}{l}\text { Strong; Risk level } \\
\text { IV }\end{array}$ \\
\hline $\begin{array}{l}\text { Rock } \\
\text { thickness }\end{array}$ & $\begin{array}{l}\text { Thick; Risk level } \\
\text { IV }\end{array}$ & $\begin{array}{l}\text { Thick; Risk level } \\
\text { IV }\end{array}$ & $\begin{array}{l}\text { Thick; Risk level } \\
\text { IV }\end{array}$ & $\begin{array}{l}\text { Thick; Risk level } \\
\text { IV }\end{array}$ & $\begin{array}{l}\text { Thick; Risk level } \\
\text { IV }\end{array}$ \\
\hline $\begin{array}{l}\text { Rock } \\
\text { formations }\end{array}$ & $\begin{array}{l}\mathrm{S}_{2-3} \mathrm{wn}-\mathrm{P}_{1} \mathrm{l} \\
\text { Between two } \\
\text { water- separated } \\
\text { strata; Risk level } \\
\text { II }\end{array}$ & $\begin{array}{l}\mathrm{S}_{2-3} \text { wn- } \mathrm{P}_{1} \mathrm{l} \\
\text { Between two } \\
\text { water- separated } \\
\text { strata; Risk level } \\
\text { II }\end{array}$ & $\begin{array}{l}\mathrm{S}_{2-3} \mathrm{wn}-\mathrm{P}_{1} \mathrm{l} \\
\text { Between two } \\
\text { water- separated } \\
\text { strata; Risk level } \\
\text { II }\end{array}$ & $\begin{array}{l}\mathrm{S}_{2-3} \mathrm{wn}-\mathrm{P}_{1} \mathrm{l} \\
\text { Between two } \\
\text { water- separated } \\
\text { strata; Risk level } \\
\text { II }\end{array}$ & $\begin{array}{l}\mathrm{P}_{1} \mathrm{l} \text { Above water } \\
\text { layer; Risk level } \\
\text { II }\end{array}$ \\
\hline Fault & Risk level I & Risk level I & Risk level I & Risk level I & Risk level I \\
\hline Wrinkle & $\begin{array}{ll}\text { anticlinal axis } & \text {-slope } \\
\text { Risk level II } & \\
\end{array}$ & $\begin{array}{l}\text { synclinal shaft, } \\
\text { fold transition } \\
\text { Risk level IV }\end{array}$ & $\begin{array}{l}\text { anticlinal } \\
\text { axis-slope } \\
\text { Risk level IV }\end{array}$ & $\begin{array}{l}\text { slope Risk level } \\
\text { III }\end{array}$ & $\begin{array}{l}\text { synclinal shaft, } \\
\text { fold transition } \\
\text { Risk level IV }\end{array}$ \\
\hline $\begin{array}{l}\text { Channels and } \\
\text { fissures }\end{array}$ & $\begin{array}{l}\text { complete rock } \\
\text { mass Risk level II }\end{array}$ & $\begin{array}{l}\text { complete rock } \\
\text { mass Risk level II }\end{array}$ & $\begin{array}{lr}\text { joints } & \text { or fracture } \\
\text { develop } & \text { Risk } \\
\text { level III } & \\
\end{array}$ & $\begin{array}{l}\text { complete rock } \\
\text { mass Risk level II }\end{array}$ & $\begin{array}{lr}\text { joints } & \text { or fracture } \\
\text { develop } & \text { Risk } \\
\text { level III } & \\
\end{array}$ \\
\hline $\begin{array}{l}\text { Grol } \\
\text { deve }\end{array}$ & $\begin{array}{l}\text { Low impact of } \\
\text { groundwater; } \\
\text { Risk level II }\end{array}$ & $\begin{array}{l}\text { Low impact of } \\
\text { groundwater; } \\
\text { Risk level II }\end{array}$ & $\begin{array}{l}\text { Low impact of } \\
\text { groundwater; } \\
\text { Risk level II }\end{array}$ & $\begin{array}{l}\text { Low impact of } \\
\text { groundwater; } \\
\text { Risk level II }\end{array}$ & $\begin{array}{l}\text { Low impact of } \\
\text { groundwater; } \\
\text { Risk level II }\end{array}$ \\
\hline $\begin{array}{l}\text { Atmospheric } \\
\text { precipitation( } \\
\text { mean annual } \\
\text { precipitation) }\end{array}$ & $\begin{array}{l}\text { 1243mm } \\
\text { level IV }\end{array}$ & $\begin{array}{l}\text { 1243mm } \\
\text { level IV }\end{array}$ & $\begin{array}{l}\text { 1243mm } \\
\text { level IV }\end{array}$ & $\begin{array}{ll}\text { 1243mm } & \text { Risk } \\
\text { level IV } & \end{array}$ & $\begin{array}{l}\text { 1243mm } \\
\text { level IV }\end{array}$ \\
\hline $\begin{array}{l}\text { groundwater } \\
\text { level } \\
\text { difference /m }\end{array}$ & $\begin{array}{l}\text { Above } \\
\text { groundwater level } \\
\text { Risk level I }\end{array}$ & $\begin{array}{l}\text { Above } \\
\text { groundwater level } \\
\text { Risk level I }\end{array}$ & $\begin{array}{l}\text { Above } \\
\text { groundwater level } \\
\text { Risk level I }\end{array}$ & $\begin{array}{l}\text { Above } \\
\text { groundwater level } \\
\text { Risk level I }\end{array}$ & $\begin{array}{l}\text { Above } \\
\text { groundwater level } \\
\text { Risk level I }\end{array}$ \\
\hline $\begin{array}{l}\text { surface Karst } \\
\text { morphology }\end{array}$ & $\begin{array}{l}\text { Karst depression } \\
\text { is weak Risk level } \\
\text { I }\end{array}$ & $\begin{array}{l}\text { Karst depression } \\
\text { is weak Risk level } \\
\text { I }\end{array}$ & $\begin{array}{l}\text { Karst depression } \\
\text { is weak Risk level } \\
\text { I }\end{array}$ & $\begin{array}{lr}\text { Visible } & \text { Karst } \\
\text { depressions } & \text { on } \\
\text { the surface } & \text { Risk } \\
\text { level II } & \\
\end{array}$ & $\begin{array}{lr}\text { Visible } & \text { Karst } \\
\text { depressions } & \text { on } \\
\text { the surface } & \text { Risk } \\
\text { level II } & \\
\end{array}$ \\
\hline
\end{tabular}

Classifications and risk assessments of water inrush in each mileage segments in table8 brought to membership function. In language description, karwowski fuzzy membership function is used. In numerical description triangle membership function is used. Eigenvectors and membership function is used in formula 2 to calculate Fuzzy Estimations. And water inrush risk got from estimations as shown in table 9. 
The calculation results of the engineering show that the hazard level of the water inrush is II-IV and appropriate risk control measures can be taken to reduce the potential of water inrush. The risk assessment of water inrush at the exit of tunnel is dangerous, so it should be paid attention in the construction. The results of risk assessment are basically compound with engineering design description. Therefore, it can be known that the model of water inrush risk assessment for tunnels in Guizhou Province is reliable.

Table 9 Probabilistic rating of water inrush

\begin{tabular}{|l|l|l|l|l|l|}
\hline & \multicolumn{3}{|l|}{ Fuzzy Estimation } & water inrush risk \\
\hline $\begin{array}{l}\text { Left tunnel ZK66+020 ZK66+607; } \\
\text { Right tunnel YK65+970 YK66+600 }\end{array}$ & 0.28 & 0.377 & 0.181 & 0.163 & Risk level II; Risk medium \\
\hline $\begin{array}{l}\text { Left tunnel ZK66+607 ZK66+707; } \\
\text { Right tunnel YK66+600 YK66+700 }\end{array}$ & 0.237 & 0.27 & 0.27 & 0.224 & Risk level III; Risk high \\
\hline $\begin{array}{l}\text { Left tunnel ZK66+707 ZK67+775; } \\
\text { Right tunnel YK66+700 YK67+766 }\end{array}$ & 0.262 & 0.37 & 0.198 & 0.17 & Risk level II; Risk medium \\
\hline $\begin{array}{l}\text { Left tunnel ZK66+775 ZK66+890; } \\
\text { Right tunnel YK66+766 YK66+900 }\end{array}$ & 0.156 & 0.291 & 0.327 & 0.226 & Risk level III; Risk high \\
\hline $\begin{array}{l}\text { Left tunnel ZK66+890 ZK67+028; } \\
\text { Right tunnel YK66+900 YK66+990 }\end{array}$ & 0.138 & 0.249 & 0.282 & 0.331 & Risk level IV; Risky \\
\hline
\end{tabular}

\section{Conclusion}

The research based on the characters of highway tunnel in Guizhou province, using fuzzy analytic hierarchy process to establish risk evaluation model on water inrush. In the process of mode, risk factors are evaluated, based on statistical analysis on water inrush in china, and on the characters of tunnel in Guizhou province. Considered similar projects and survey from experts, relative scale methodology is used to obtain weight value on risk factors, when Saulty matrix is used. The influence factors were calculated by using the triangle membership function and the fuzzy membership function of karwowski. The model results are processed based on the maximum value method. The mode is used in tunnel in Guizhou province, to obtain the possibility of water inrush. Model calculation results are in conformity with engineering evaluation. Consequently, the mode is reasonable, which could be used in evaluate water inrush in Guizhou tunnel.

\section{References}

[1] Li Ji, Chang Le. Study on Karst Water Inrush Risk Assessment Model Based on Karst Distribution Analysis [J] Tunnel Construction, 2015,08(08):792-801.

[2] Ge Yanhui. Study on water inrush risk and early warning mechanism of karst tunnel [D]. Shandong University, 2010

[3] Ma Dong. Study on impact mechanism of deep buried Karst to tunnel safety and the treatment technique. [D]. Beijing Jiaotong University. 2012

[4] Li Liping, Li Shucai, Chen Jun. Construction license mechanism and its application based on karst water inrush risk evaluation [J]. Chinese Journal of Rock Mechanics and Engineering, 2011,30(07): 1345-1355

[5] Yuan Long. Risk assessment in Tunnel Portal Landslide Based on Fuzzy AHP Comprehensive Evaluation. [D]. Chang an University. 2010

[6] Yu Yongyan. Tunnel Collapse Risk Assessment under Fuzzy Analytic Hierarchy Process[J]. Transportation science \& Technology, 2016,05(11):111-114.

[7] Karwowski, Waldemar, Anil Mital. Applications of approximate reasoning in risk analysis, In Applications of Fuzzy Set theory in Human Factors,ed.Waldemar and Anil Mital[M], Amsterdam, 
New York: Elsevier, 1986, 227-243

[8] Sun Xiyu. Fuzzy Mathematics and Its Application [M]. Wuhan. Wuhan University Press. 2002

[9] Wei Wushu. Study on information construction and numerical simulation of high railway karsts tunnel with shallow buried and large cross-section. [D]. Hunan University of Science and Technology ,2012.

[10] Xu zhenhao, Li shucai, Li liping. Risk assessment of water or mud inrush of karst tunnels based on analytica hierarchy process. [J]. Rock and Soil Mechanics., 2011,32 (6): 1757-1766 